\title{
ANALISIS KESTABILAN MODEL PENYEBARAN PENYAKIT HEPATITIS A DENGAN VAKSINASI DAN SANITASI
}

\author{
Nurfitriana, Mariatul Kiftiah, Yudhi
}

\begin{abstract}
INTISARI
Pada penelitian ini dibahas pemodelan penyebaran penyakit hepatitis A. Penyakit ini dapat menular jika seseorang menelan makanan atau minuman yang telah terkontaminasi oleh feses dari orang yang terinfeksi hepatitis A. Model matematika yang dibentuk pada penelitian ini membagi populasi menjadi tiga subpopulasi, yaitu susceptible, infected, dan recovered. Model penyebaran penyakit hepatitis A pada penelitian ini memperhatikan pemberian vaksinasi dan sanitasi yang dilakukan. Berdasarkan model yang terbentuk diperoleh dua titik kesetimbangan, yaitu titik kesetimbangan bebas penyakit $\left(E_{1}\right)$ yang bersifat stabil asimtotik dan titik kesetimbangan endemik $\left(E_{2}\right)$ yang bersifat tidak stabil. Hasil simulasi menunjukkan bahwa faktor sanitasi dapat menurunkan puncak endemik serta mengurangi populasi individu yang terinfeksi hepatitis A di suatu wilayah tertentu.
\end{abstract}

Kata Kunci : model SIR, sanitasi, titik kesetimbangan

\section{PENDAHULUAN}

Perkembangan dan kemajuan ilmu dan teknologi tidak bisa dipisahkan dari matematika. Hampir seluruh aktifitas manusia berkaitan dengan matematika. Peran matematka dalam kehidupan sehari-hari maupun dalam ilmu-ilmu yang lain disajikan dalam pemodelan matematika. Representasi matematika yang dihasilkan dari pemodelan matematika dikenal sebagai model matematika. Model matematika banyak digunakan dalam disiplin ilmu dan bidang yang berbeda. Salah satunya, bidang kesehatan, yaitu model matematika penyebaran penyakit hepatitis A. Hepatitis A adalah penyakit hati yang disebabkan oleh virus hepatitis A. Virus ini menyebar ketika orang yang tidak terinfeksi menelan makanan atau minuman yang telah terkontaminasi oleh feses dari orang yang terinfeksi. Penyakit ini dapat menimbulkan gejala seperti mual, muntah, lemas, hilang nafsu makan, serta kulit dan sklera mata menjadi kuning [1].

Diperkirakan terdapat 1,5 juta kasus hepatitis A di dunia setiap tahunnya [1]. Di Indonesia hepatitis A masih merupakan bagian terbesar dari kasus-kasus hepatitis akut yang dirawat, yaitu berkisar antara 39,8\% - 68,3\% [2]. Di Kalimantan Barat, khususnya Kota Singkawang hepatitis A menjadi salah satu penyakit yang banyak diderita oleh warga Kota Singkawang, berdasarkan data yang diperoleh dari Dinas Kesehatan Kota Singkawang terdapat 169 kasus hepatitis A di Kota Singkawang pada bulan Agustus 2018 sampai September 2018.

Menurut WHO, cara terbaik untuk mencegah penularan hepatitis A adalah dengan memperbaiki sanitasi lingkungan dan pemberian vaksinasi [1]. Sanitasi total meliputi sumber air bersih, gaya hidup sehat, dan saluran pembuangan. Menjaga kebersihan terhadap diri sendiri dan lingkungan sekitar tempat tinggal merupakan upaya awal yang sangat penting sebagai proses pencegahan dini sebelum terjangkit hepatitis A. Selain itu, pemberian vaksinasi yang dimaksudkan sebagai perlindungan juga merupakan bagian dari pencegahan penyakit hepatitis A.

Penelitian ini memodelkan penyebaran penyakit hepatitis A, menganalisis kestabilan model penyebaran penyakit hepatitis A di sekitar titik kesetimbangan, dan menginterpretasi model yang telah dibentuk dengan melakukan simulasi numerik serta mengetahui pengaruh sanitasi terhadap populasi manusia yang terinfeksi hepatitis A. Penelitian ini membahas tentang model penyebaran penyakit 
hepatitis A dengan memperhatikan pemberian vaksinasi dan sanitasi yang dilakukan. Model yang digunakan merupakan model SIR (Susceptible-Infected-Recovered) dan data yang digunakan adalah data penderita hepatitis A di Kota Singkawang pada bulan Agustus 2018 sampai September 2018.

Analisis kestabilan model penyebaran penyakit hepatitis A dimulai dengan menyusun asumsiasumsi dan mendefinisikan parameter yang digunakan pada model yang kemudian dibentuk ke dalam diagram transfer model matematika penyebaran penyakit hepatitis A. Berdasarkan diagram transfer tersebut dibentuk model matematika penyebaran penyakit hepatitis A. Kemudian, menentukan titik kesetimbangan dari model. Model yang diperoleh dalam penelitian ini adalah model dalam bentuk persamaan diferensial nonlinear yang memiliki dua titik kesetimbangan yaitu titik kesetimbangan bebas penyakit dan titik kesetimbangan endemik. Langkah selanjutnya, melakukan linearisasi dengan membentuk matriks Jacobian dari sistem persamaan yang telah dibentuk [3]. Berdasarkan matriks Jacobian tersebut, diperoleh polinomial karakteristik. Selanjutnya, menentukan kestabilan sistem di sekitar titik kesetimbangan menggunakan kriteria Routh-Hurwitz [4]. Langkah terakhir adalah melakukan simulasi numerik dengan mensubstitusikan beberapa nilai parameter yang telah ditentukan.

\section{Model Matematika Penyebaran Penyakit Hepatitis A}

Pembentukan model matematika penyebaran penyakit hepatitis A dimulai dengan membagi populasi menjadi tiga subpopulasi yaitu, subpopulasi individu yang rentan (susceptible), subpopulasi individu yang terinfeksi hepatitis A (infected), dan subpopulasi individu yang telah sembuh dan akan kebal terhadap penyakit hepatitis A (recovered). Pembentukan model matematika pada penelitian ini memperhatikan interaksi antara individu yang rentan dengan individu yang terinfeksi disertai pengaruh vaksinasi yang diberikan dan sanitasi yang dilakukan. Berikut beberapa asumsi yang digunakan dalam pembentukan model penyebaran penyakit hepatitis A, yaitu :

1. Pemodelan dilakukan pada populasi tertutup, yang berarti migrasi atau perpindahan penduduk tidak mempengaruhi jumlah populasi.

2. Pemodelan tidak memperhatikan masa inkubasi.

3. Populasi bercampur secara homogen, artinya setiap individu memiliki kemungkinan yang sama dalam melakukan kontak dengan individu yang lain.

4. Individu yang terinfeksi dapat sembuh atau meninggal karena penyakit.

5. Hanya ada satu penyakit yang menyebar dalam populasi.

6. Tingkat keberhasilan vaksinasi $100 \%$. Hal ini berarti setiap individu yang telah divaksin akan kebal terhadap penyakit.

7. Individu yang sudah sembuh dinyatakan kebal terhadap penyakit.

Proses penyebaran penyakit hepatitis A dapat digambarkan dalam diagram transfer berikut ini

$\sigma$

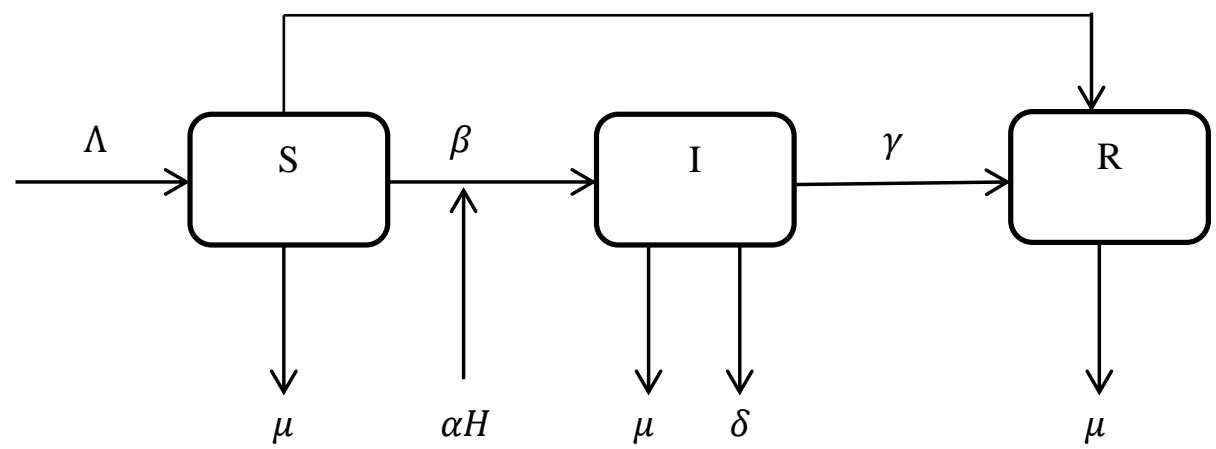

Gambar 1. Diagram transfer proses penyebaran penyakit hepatitis A 
Model matematika penyebaran penyakit hepatitis A diperoleh sebagai berikut:

$$
\left.\begin{array}{l}
\frac{d S}{d t}=\Lambda-(\beta-\alpha H) S \frac{I}{N}-\sigma S-\mu S \\
\frac{d I}{d t}=(\beta-\alpha H) S \frac{I}{N}-\gamma I-\delta I-\mu I \\
\frac{d R}{d t}=\gamma I+\sigma S-\mu R
\end{array}\right\}
$$

dimana $\Lambda, \mu, \beta, \gamma, \delta, \sigma, \alpha>0, N, S, I, R \geq 0$, dan $0 \leq H \leq 1$, dengan parameter sebagai berikut:

$\Lambda$ adalah tingkat kelahiran, $\beta$ adalah tingkat penularan dari individu yang terinfeksi terhadap individu yang rentan, $\mu$ adalah tingkat kematian secara alami atau yang tidak disebabkan oleh penyakit hepatitis A, $\delta$ adalah tingkat kematian karena penyakit hepatitis A, $\gamma$ adalah tingkat kesembuhan individu yang terinfeksi, $\alpha$ adalah persentase keberhasilan sanitasi, $\sigma$ adalah tingkat vaksinasi, $H$ adalah level sanitasi, $N$ adalah jumlah populasi manusia, $S$ adalah jumlah individu pada subpopulasi susceptible, $I$ adalah jumlah individu pada subpopulasi infected, $R$ adalah jumlah individu pada subpopulasi recovered

Selanjutnya menentukan titik kesetimbangan dari Sistem Persamaan (1). Pada Sistem Persamaan (1) terdapat suatu fungsi sanitasi $C(H)=\beta-\alpha H$ dengan $0 \leq H \leq 1$, oleh karena itu sulit untuk menemukan titik kesetimbangan dari sistem tersebut [5]. Sehingga harus disubstitusikan suatu nilai $\mathrm{H}$ ke Sistem Persamaan (1). Untuk selanjutnya titik kesetimbangan hanya akan diselidiki pada saat $H=1$ atau sanitasi maksimal. Berdasarkan Sistem Persamaan (1) diperoleh dua titik kesetimbangan yaitu titik kesetimbangan bebas penyakit $\left(E_{1}\right)$ dan titik kesetimbangan endemik $\left(E_{2}\right)$ sebagai berikut:

$$
\begin{aligned}
E_{1}= & \left(S_{1}=\frac{\Lambda}{(\sigma+\mu)}, I_{1}=0, R_{1}=\frac{\sigma \Lambda}{(\sigma+\mu) \mu}\right) \\
E_{2}= & \left(S_{2}=-\frac{N(\gamma+\delta+\pi)}{\alpha-\beta}, I_{2}=\frac{N \delta \mu+N \gamma \mu+N \gamma \sigma+N \mu^{2}+N \mu \sigma+\Lambda \alpha-\Lambda \beta}{\alpha \delta+\alpha \gamma+\alpha \mu-\beta \delta-\beta \gamma-\beta \mu},\right. \\
R_{2}= & \left.\frac{\left(-N \delta^{2} \sigma+N \delta \gamma \mu-2 N \delta \mu \sigma+N \gamma^{2} \mu+N \gamma \mu^{2}-N \gamma \mu \sigma-N \mu^{2} \sigma+\Lambda \alpha \gamma-\Lambda \beta \gamma\right)}{\mu(\alpha-\beta)(\gamma+\delta+\mu)}\right)
\end{aligned}
$$

Titik kesetimbangan $\left(E_{1}\right)$ menunjukkan kondisi bebas penyakit hepatitis A pada suatu daerah. Pada kondisi ini tidak ada individu yang terinfeksi hepatitis A. Titik kesetimbangan $\left(E_{2}\right)$ menunjukkan masih adanya penyakit hepatitis A di suatu daerah. Pada kondisi ini masih ada individu yang terinfeksi hepatitis A.

\section{ANALISIS KESTABILAN MODEL PENYEBARAN PENYAKIT HEPATITIS A}

Analisis kestabilan titik kesetimbangan dapat menggunakan kriteria Routh-Hurwitz yaitu dengan memperhatikan nilai determinan dari submatriks utama pembuka dari matriks $\mathbf{H}$, dengan $\mathbf{H} \in \mathbb{R}^{\boldsymbol{n} \times \boldsymbol{n}}$ dapat ditulis sebagai berikut

$$
\mathbf{H}=\left[\begin{array}{cccccc}
\mathrm{a}_{1} & \mathrm{a}_{3} & \mathrm{a}_{5} & \mathrm{a}_{7} & \cdots & 0 \\
1 & \mathrm{a}_{2} & \mathrm{a}_{4} & \mathrm{a}_{6} & \cdots & 0 \\
0 & \mathrm{a}_{1} & \mathrm{a}_{3} & \mathrm{a}_{5} & \cdots & 0 \\
0 & 1 & \mathrm{a}_{2} & \mathrm{a}_{4} & \cdots & 0 \\
\vdots & \vdots & \vdots & \vdots & \ddots & \vdots \\
0 & 0 & 0 & 0 & \cdots & \mathrm{a}_{\mathrm{n}}
\end{array}\right]
$$

Syarat cukup dan perlu untuk kestabilan sistem di sekitar titik kesetimbangan yaitu jika semua determinan dari submatriks utama pembuka dari matriks $\mathbf{H}$ adalah positif. Kriteria kestabilan juga ditentukan oleh $\operatorname{det} \mathbf{H} \neq 0$ [4].

Analisis kestabilan sistem persamaan diferensial nonlinear dilakukan dengan linearisasi terlebih dahulu. Linearisasi dilakukan menggunakan matriks Jacobian pada Sistem Persamaan (1) sehingga diperoleh matriks sebagai berikut

$$
\mathbf{J}=\left(\begin{array}{ccc}
-\frac{(\beta-\alpha H) I}{N}-\sigma-\mu & \frac{(\beta-\alpha H) S}{N} & 0 \\
\frac{(\beta-\alpha H) I}{N} & \frac{(\beta-\alpha H) S}{N}-\gamma-\delta-\mu & 0 \\
\sigma & \gamma & -\mu
\end{array}\right)
$$


Selanjutnya dengan mensubstitusikan Persamaan (2) ke Persamaan (4) diperoleh matriks $\mathbf{J}_{\mathbf{1}}$ sebagai berikut

$$
\mathbf{J}_{\mathbf{1}}=\left(\begin{array}{ccc}
-\sigma-\mu & -\frac{(\beta-\alpha) \Lambda}{(\mu+\sigma) N} & 0 \\
0 & \frac{(\beta-\alpha) \Lambda}{(\mu+\sigma) N}-\gamma-\delta-\mu & 0 \\
\sigma & \gamma & -\mu
\end{array}\right)
$$

Berdasarkan matriks $\mathbf{J}_{\mathbf{1}}$ diperoleh polinomial karakteristik

$$
P(\lambda)=\lambda^{3}+A_{1} \lambda^{2}+B_{1} \lambda+C_{1}
$$

dengan nilai $A_{1}, B_{1}$, dan $C_{1}$ sebagai berikut

$$
\begin{aligned}
& A_{1}=\frac{\left(N \delta \sigma+N \delta \mu+N \gamma \mu+N \gamma \sigma+3 N \mu^{2}+4 N \mu \sigma+N \sigma^{2}+\Lambda \alpha-\Lambda \beta\right)}{(\mu+\sigma) N} \\
& B_{1}=\frac{1}{(\mu+\sigma) N}\left(2 N \delta \mu^{2}+3 N \delta \mu \sigma+N \delta \sigma^{2}+2 N \gamma \mu^{2}+3 N \gamma \mu \sigma+N \gamma \sigma^{2}+3 N \mu^{3}+5 N \mu^{2} \sigma+2 N \mu \sigma^{2}+2 \Lambda \alpha \mu\right. \\
& \quad-\Lambda \alpha \sigma-2 \Lambda \beta \mu-\Lambda \beta \sigma) \\
& C_{1}=\frac{\mu\left(N \delta \mu+N \delta \sigma+N \gamma \mu+N \gamma \sigma+N \mu^{2}+N \mu \sigma+\Lambda \alpha-\Lambda \beta\right)}{N}
\end{aligned}
$$

Dengan memperhatikan nilai koefisien pada Persamaan (5) diperoleh $a_{0}=1, a_{1}=A_{1}, a_{2}=B_{1}$, dan $a_{3}=C_{1}$ sehingga dapat dibentuk matriks Hurwitz sebagai berikut

$$
\mathbf{H}_{\mathbf{1}}=\left(\begin{array}{ccc}
A_{1} & C_{1} & 0 \\
1 & B_{1} & 0 \\
0 & A_{1} & C_{1}
\end{array}\right)
$$

Berikut determinan dari submatriks utama pembuka yang diperoleh dari matriks $\mathbf{H}_{\mathbf{1}}$

$H_{1}=A_{1}$

$H_{2}=\left|\begin{array}{cc}A_{1} & C_{1} \\ 1 & B_{1}\end{array}\right|=A_{1} B_{1}-C_{1}$

$H_{3}=\left|\begin{array}{ccc}A_{1} & C_{1} & 0 \\ 1 & B_{1} & 0 \\ 0 & A_{1} & C_{1}\end{array}\right|=A_{1} B_{1} C_{1}-C_{1}{ }^{2}$

Berdasarkan kriteria Routh-Hurwitz, dari Persamaan (6), (7), dan (8) dapat disimpulkan bahwa titik kesetimbangan $\left(E_{1}\right)$ akan stabil asimtotik jika:

1. $H_{1}>0$, berarti $A_{1}>0$

2. $H_{2}>0$, berarti $A_{1} B_{1}>C_{1}$

3. $H_{3}>0$, berarti $A_{1} B_{1}>C_{1}$

Selanjutnya dengan mensubstitusikan Persamaan (3) ke Persamaan (4) diperoleh matriks $\mathbf{J}_{2}$ sebagai berikut

$$
\mathbf{J}_{2}=\left(\begin{array}{ccc}
-\frac{(\beta-a)\left(N \delta \mu+N \delta \sigma+N \gamma \mu+N \gamma \sigma+N \mu^{2}+N \mu \sigma+\Lambda \alpha-\Lambda \beta\right)}{(\alpha \delta+\alpha \gamma+\alpha \mu-\beta \delta-\beta \gamma-\beta \eta) N}-\sigma-\mu & \frac{(\beta-\alpha)(\gamma+\delta+\mu)}{\alpha-\beta} & 0 \\
\frac{(\beta-a)\left(N \delta \mu+N \delta \sigma+N \gamma \mu+N \gamma \sigma+N \mu^{2}+N \mu \sigma+\Lambda \alpha-\Lambda \beta\right)}{(\alpha \delta+\alpha \gamma+\alpha \mu-\beta \delta-\beta \gamma-\beta \eta) N} & -\frac{(\beta-\alpha)(\gamma+\delta+\mu)}{\alpha-\beta}-\gamma-\delta-\mu & 0 \\
\sigma & -\mu
\end{array}\right)
$$

Berdasarkan matriks $\mathbf{J}_{2}$ diperoleh polinomial karakteristik

$$
P(\lambda)=\lambda^{3}+A_{2} \lambda^{2}+B_{2} \lambda+C_{2}
$$

dengan nilai $A_{2}, B_{2}$, dan $C_{2}$ sebagai berikut

$$
\begin{gathered}
A_{2}=-\frac{\left(-N \delta \mu-N \gamma \mu-N \mu^{2}+\Lambda \alpha-\Lambda \beta\right)}{N(\gamma+\delta+\mu)} \\
B_{2}=-\frac{1}{N((\gamma+\delta+\mu))}\left(N \delta^{2} \mu+N \delta^{2} \sigma+2 N \delta \gamma \sigma+2 N \delta \mu^{2}+2 N \delta \mu \sigma+N \gamma^{2} \mu+N \gamma^{2} \sigma+2 N \gamma \mu^{2}+2 N \gamma \mu \sigma\right. \\
\left.\quad+N \mu^{3}+N \mu^{2} \sigma+\Lambda \alpha \delta+\Lambda \alpha \gamma+2 \Lambda \alpha \mu-\Lambda \beta \delta-\Lambda \beta \gamma-2 \Lambda \beta \mu\right)
\end{gathered}
$$


$C_{2}=-\frac{\mu\left(N \delta \mu+N \delta \sigma+N \gamma \mu+N \gamma \sigma+N \mu^{2}+N \mu \sigma+\Lambda \alpha-\Lambda \beta\right)}{N}$

Dengan memperhatikan nilai koefisien pada Persamaan (8) diperoleh $a_{0}=1, a_{1}=A_{2}, a_{2}=B_{2}$, dan $a_{3}=C_{2}$ sehingga dapat dibentuk matriks Hurwitz sebagai berikut

$$
\mathbf{H}_{2}=\left(\begin{array}{ccc}
A_{2} & C_{2} & 0 \\
1 & B_{2} & 0 \\
0 & A_{2} & C_{2}
\end{array}\right)
$$

Berikut determinan dari submatriks utama pembuka dari matriks $\mathbf{H}_{2}$

$H_{4}=A_{2}$

$H_{5}=\left|\begin{array}{cc}A_{2} & C_{2} \\ 1 & B_{2}\end{array}\right|=A_{2} B_{2}-C_{2}$

$H_{6}=\left|\begin{array}{ccc}A_{2} & C_{2} & 0 \\ 1 & B_{2} & 0 \\ 0 & A_{2} & C_{2}\end{array}\right|=A_{2} B_{2} C_{2}-C_{2}{ }^{2}$

Berdasarkan kriteria Routh-Hurwitz, dari Persamaan (9), (10), dan (11) dapat disimpulkan bahwa titik kesetimbangan $\left(E_{2}\right)$ akan stabil asimtotik jika:

1. $H_{4}>0$, berarti $A_{2}>0$

2. $H_{5}>0$, berarti $A_{2} B_{2}>C_{2}$

3. $H_{6}>0$, berarti $A_{2} B_{2}>C_{2}$

\section{SIMULASI DAN INTERPRETASI MODEL PENYEBARAN PENYAKIT HEPATITIS A DI KOTA SINGKAWANG}

Simulasi model dalam penelitian ini bertujuan untuk memberikan gambaran dinamika penyebaran penyakit hepatitis A. Simulasi model dilakukan dengan mensubstitusikan nilai parameter yang telah diperoleh dari beberapa sumber. Nilai parameter yang digunakan dalam penelitian ini diberikan pada Tabel 1

Tabel 1. Nilai Parameter Penyebaran Penyakit Hepatitis A

\begin{tabular}{ccc}
\hline Parameter & Nilai (per bulan) & Sumber \\
\hline$\Lambda$ & $1,71 \times 10^{-3}$ & {$[6]$} \\
$\beta$ & 1,4286 & {$[1]$} \\
$\mu$ & $1,17 \times 10^{-3}$ & {$[6]$} \\
$\delta$ & $2,5 \times 10^{-4}$ & {$[7]$} \\
$\gamma$ & $8,25 \times 10^{-2}$ & {$[1]$} \\
$\sigma$ & $6,23 \times 10^{-2}$ & {$[8]$} \\
$\alpha$ & 1,4281 & {$[5]$} \\
\hline
\end{tabular}

Selanjutnya substitusi nilai-nilai parameter pada Tabel 1 ke Sistem Persamaan (1) sehingga diperoleh

$$
\begin{aligned}
& \frac{d S}{d t}=0,00171-0,0005 \frac{S I}{N}-0,06347 S \\
& \frac{d I}{d t}=0,0005 \frac{S I}{N}-0,08392 I \\
& \frac{d R}{d t}=0,0825 I-0,00117 R+0,0623 S
\end{aligned}
$$

dengan nilai $N=215.296$ yaitu jumlah populasi manusia di Kota Singkawang, serta nilai awal $S(0)=108.090, I(0)=169$, dan $R(0)=107.010$. Dengan menggunakan nilai parameter pada Tabel 1, diperoleh determinan Routh-Hurwitz pada Persamaan (5), (6), dan (7) sebagai berikut 
$H_{1}=6,8844 \times 10^{9}, H_{2}=1,7543 \times 10^{18}$ dan $H_{3}=1,0932 \times 10^{13}$. Dari hasil tersebut diketahui bahwa semua nilai determinan Routh-Hurwitz berupa bilangan real positif, sehingga berdasarkan kriteria Routh-Hurwitz dapat disimpulkan bahwa titik kesetimbangan bebas penyakit bersifat stabil asimtotik. Selanjutnya diperoleh determinan Routh-Hurwitz pada Persamaan (9), (10),dan (11) sebagai berikut $H_{4}=8,2398 \times 10^{-6}, H_{5}=6,2315 \times 10^{-6}$, dan $H_{6}=-3,8834 \times 10^{-11}$. Dari hasil tersebut diketahui bahwa terdapat satu determinan Routh-Hurwitz berupa bilangan real negatif, sehingga berdasarkan kriteria Routh-Hurwitz dapat disimpulkan bahwa titik kesetimbangan endemik bersifat tidak stabil.

Selanjutnya hasil simulasi numerik model penyebaran penyakit Hepatitis A untuk 20 tahun mendatang dapat dilihat pada Gambar 2 berikut:

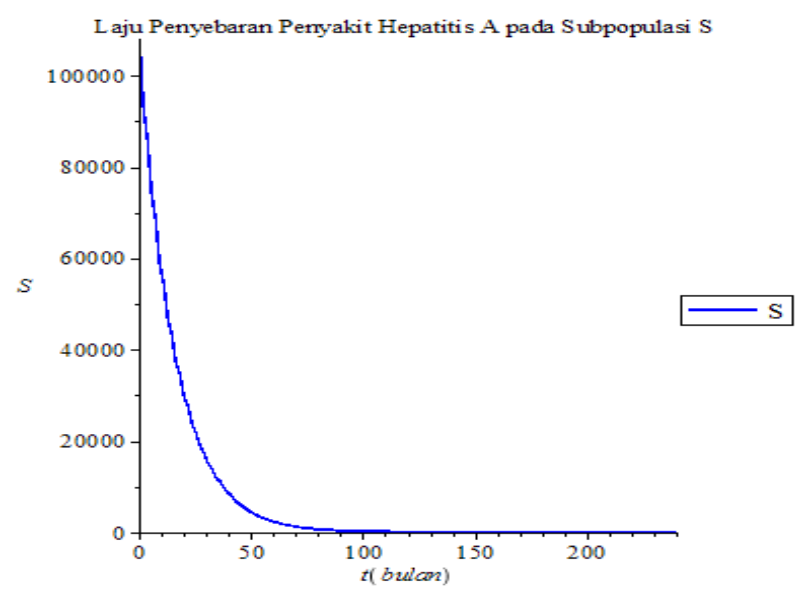

(a)

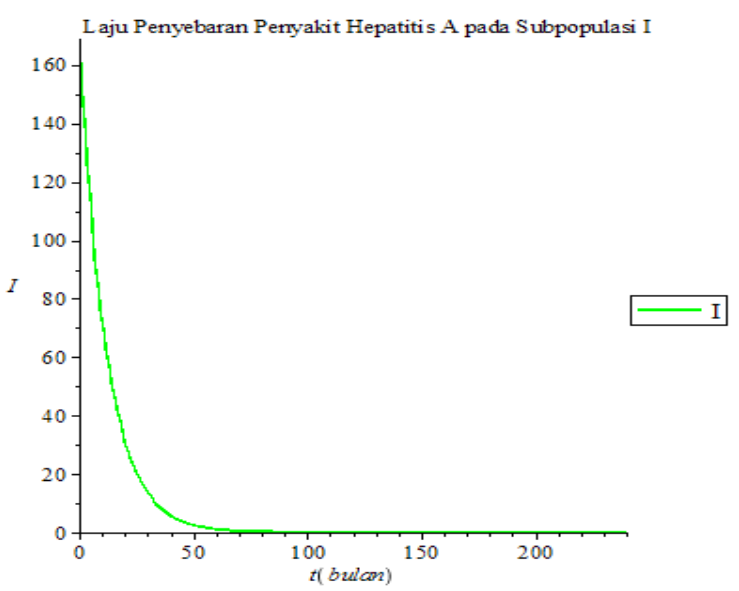

(b)

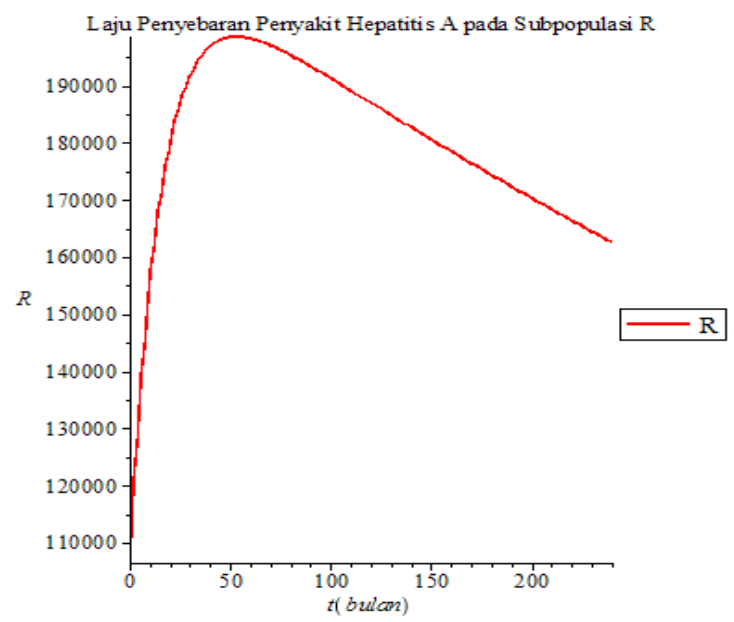

(c)

Gambar 2. Grafik Simulasi Penyebaran Penyakit Hepatitis A pada Setiap Subpopulasi

Berdasarkan Gambar 2(a), jumlah individu pada subpopulasi $S$ mengalami penurunan yang cukup drastis, dari mula-mula 108.090 individu yang rentan terinfeksi hepatitis A pada saat $t=0$ bulan sehingga hampir tidak ada individu yang rentan terinfeksi hepatitis A pada saat $t$ lebih dari 183 bulan. Hal ini terjadi karena meningkatnya individu pada subpopulasi $I$ pada waktu tertentu sehingga menyebabkan interaksi antara manusia yang terinfeksi dengan manusia yang rentan juga meningkat yang berakibat pindahnya individu pada subpopulasi $S$ ke subpopulasi $I$ serta karena pengaruh pemberian vaksin hepatitis A kepada individu pada subpopulasi $S$ yang menyebabkan berpindahnya individu pada subpopulasi $S$ ke subpopulasi $R$ dan adanya kematian alami sehingga jumlah individu pada subpopulasi $S$ menurun.

Berdasarkan Gambar 2(b) jumlah individu pada subpopulasi I mengalami penurunan dari mulamula 169 individu yang terinfeksi hepatitis A pada saat $t=0$ bulan sehingga hampir tidak ada 
individu yang terinfeksi pada saat $t$ lebih dari 61 bulan. Hal ini terjadi karena individu pada subpopulasi $I$ yang telah sembuh dari hepatitis A berpindah ke subpopulasi $R$, serta adanya kematian alami dan kematian yang disebabkan penyakit hepatitis A sehingga menyebabkan jumlah individu pada subpopulasi $I$ menurun.

Berdasarkan Gambar 2(c), jumlah individu pada subpopulasi $R$ mengalami peningkatan dari mulamula terdapat 107.010 individu yang kebal terhadap penyakit hepatitis A menjadi sekitar 195.000 individu kurang lebih pada $t=45$ bulan. Hal ini terjadi karena keberhasilan pemberian vaksin yang cukup besar sehingga individu pada subpopulasi $S$ mengalami kekebalan terhadap penyakit hepatitis A yang menyebabkan individu pada subpopulasi $R$ juga mengalami peningkatan pada rentang waktu tersebut. Kurang lebih pada saat $t$ lebih dari 60 bulan dan seterusnya jumlah individu pada subpopulasi $R$ mengalami penurunan. Hal ini terjadi karena menurunnya jumlah individu pada subpopulasi $S$ dan juga dipengaruhi oleh kematian alami dari populasi manusia.

Selanjutnya dilakukan simulasi pada nilai $H$ untuk mengetahui pengaruh tingkat sanitasi terhadap jumlah individu pada subpopulasi $I$. Hal tersebut cukup penting untuk dijadikan acuan dalam pengambilan tindakan pencegahan hepatitis A. Dengan demikian diharapkan penyebaran penyakit hepatitis A yang terjadi akan berkurang. Simulasi tingkat sanitasi pada beberapa nilai, yaitu $H=$ $0, H=0,25, H=0,5, H=0,75$, dan $H=1$ dapat dilihat pada Tabel 2 berikut

Tabel 2. Jumlah Individu pada Subpopulasi $I$ dengan Simulasi Nilai $H$

\begin{tabular}{rrc}
\hline \multicolumn{1}{r}{$H$} & Puncak endemik & $t$ (dalam bulan $)$ \\
\hline 0 & 209.951 & 33 \\
0,25 & 18.240 & 31 \\
0,5 & 1.878 & 22 \\
0,75 & 282 & 11 \\
1 & 169 & 0
\end{tabular}

Berdasarkan Tabel 2, terlihat bahwa semakin besar nilai $H$ maka puncak endemik semakin menurun. Secara visual penurunan jumlah individu pada subpopulasi $I$ dapat dilihat pada Gambar 3 berikut

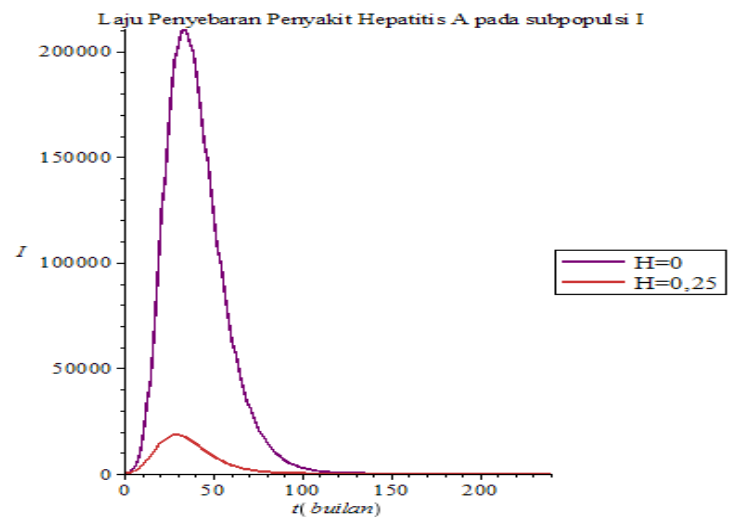

(a)

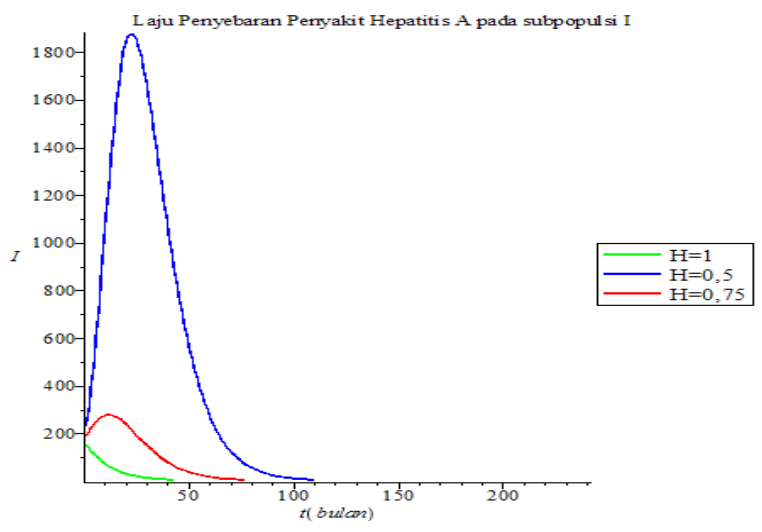

(b)

Gambar 3. Jumlah Individu pada Subpopulasi $I$ dengan Simulasi Nilai $H$

Pada Gambar 3 terlihat bahwa semakin baik sanitasi di suatu wilayah, maka jumlah populasi individu yang terinfeksi semakin berkurang. 


\section{PENUTUP}

Berdasarkan pembahasan yang telah dipaparkan, maka dapat ditarik kesimpulan, yaitu:

1. Model matematika penyebaran penyakit hepatitis A dengan vaksinasi dan sanitasi yang terbentuk adalah

$$
\begin{aligned}
& \frac{d S}{d t}=\Lambda-(\beta-\alpha H) S \frac{I}{N}-\sigma S-\mu S \\
& \frac{d I}{d t}=(\beta-\alpha H) S \frac{I}{N}-\gamma I-\delta I-\mu I \\
& \frac{d R}{d t}=\gamma I+\sigma S-\mu R
\end{aligned}
$$

2. Analisis kestabilan model matematika penyebaran penyakit hepaitis A menghasilkan dua titik kesetimbangan, yaitu:

a. Titik kesetimbangan bebas penyakit $\left(E_{1}\right)$

$$
E_{1}=\left(S_{1}=\frac{\Lambda}{(\sigma+\mu)}, I_{1}=0, R_{1}=\frac{\sigma \Lambda}{(\sigma+\mu) \mu}\right)
$$

b. Titik kesetimbangan endemik $\left(E_{2}\right)$

$$
\begin{aligned}
E_{2}=\left(S_{2}\right. & =-\frac{N(\gamma+\delta+\pi)}{\alpha-\beta}, \\
I_{2} & =\frac{N \delta \mu+N \gamma \mu+N \gamma \sigma+N \mu^{2}+N \mu \sigma+\Lambda \alpha-\Lambda \beta}{\alpha \delta+\alpha \gamma+\alpha \mu-\beta \delta-\beta \gamma-\beta \mu}, \\
R_{2} & \left.=\frac{\left(-N \delta^{2} \sigma+N \delta \gamma \mu-2 N \delta \mu \sigma+N \gamma^{2} \mu+N \gamma \mu^{2}-N \gamma \mu \sigma-N \mu^{2} \sigma+\Lambda \alpha \gamma-\Lambda \beta \gamma\right)}{\mu(\alpha-\beta)(\gamma+\delta+\mu)}\right)
\end{aligned}
$$

3. Simulasi menunjukkan bahwa peningkatan sanitasi dapat menurunkan puncak endemik dan menurunkan jumlah individu yang terinfeksi hepatitis A.

\section{DAFTAR PUSTAKA}

[1] WHO. World Health Statistics 2018. Luxembourg: WHO; 2018.

[2] Anggraini WO. Analisis Model SIR dengan Imigrasi dan Sanitasi Pada Penyakit Hepatitis A di Jember. Prosiding Seminar Nasional Matematika. 2014: 346-355.

[3] Perko L. Differential Equations and Dynamical Systems Third Edition. New York: Springer Verlag; 2001.

[4] Kraus FJ, Mansour M, Sebek M. Hurwitz Matrix for Polynomial Matrices. International Series of Numerical Mathematics. Switzerland. 1996;121:67-74.

[5] Guimaraens MA, Codeço CT. Experiment with Mathematical Models to Simulate Hepatitis A Population Dinamics under Different Levels of Endemicity. Rio de Janeiro: 2005; 21(5):1531-1539.

[6] BPS Kota Singkawang. Statistik Daerah Kota Singkawang 2018. Singkawang: BPS Kota Singkawang; 2018.

[7] Widoyono. Penyakit Tropis: Epidemiologi, Penularan, Pencegahan, dan Pemberantasannya. Jakarta: Erlangga; 2011.

[8] Meryantie A. Analisis Peluang Umur Terjangkit Demam Berdarah di Kota Bandung dengan Menggunakan Model Parametrik. Bandung: Universitas Padjadjaran Fakultas MIPA (Skripsi); 2005.

NURFITRIANA

MARIATUL KIFTIAH

YUDHI
: Jurusan Matematika FMIPA Untan, Pontianak, fitriana13@student.untan.ac.id : Jurusan Matematika FMIPA Untan, Pontianak, kiftiahmariatul@math.untan.ac.id : Jurusan Matematika FMIPA Untan, Pontianak, dhye_dhoank@yahoo.co.uk 